\title{
CRITERIA BASED INTERNAL ASSESSMENT OF EDUCATIONAL ACHIEVEMENTS OF STUDENTS IN TEACHING ENGLISH
}

\author{
Fatima Karigulova', Elmira Uteubayeva ${ }^{2}$ \\ ${ }^{1}$ E.A.Buketov Karaganda University, Karaganda, Kazakhstan \\ ${ }^{2}$ E.A.Buketov Karaganda University, Karaganda, Kazakhstan \\ ORCID iD:0000-0002-1648-114X
}

\begin{abstract}
This article presents theoretical and practical aspects of Criteria-Based Assessment of students' educational achievements and it shows systematic implementation of internal and external assessment at colleges. The content of the article is divided into two sections. The first section presents the theoretical part, principles and connection of criteria-based assessment with the curriculum. The second section shows approaches to criteria-based assessment, improved after the application of the Integrated Model of Criteria-Based Assessment. The article of criteria-based assessment of students' educational achievements is intended for use at colleges.
\end{abstract}

\section{INTRODUCTION}

The process of evaluating the results of students' activities is an important component of the entire educational process. Teaching, learning and assessment are interrelated, should form an integral part of teaching and learning activities (Boyle \& Charles 2011). Assessment acts as a means of teaching, since it makes it possible to track the individual progress of students in achieving the planned results in various areas of cognitive activity, provides feedback for teachers, students and their parents. At the same time, assessment and control and evaluation activities are part of universal educational activities, and, therefore, are the goal and an independent element of the content of education that needs to be formed and developed. The traditional assessment does not correspond to modern tendencies, as it has a number of disadvantages. Firstly, it is more or less subjective, since it does not have clear criteria for evaluating the achievement of the planned results of the learning process, which would be clear to all participants in the educational process. That is why there is an increase in dissatisfaction with the assessment that the teacher exposes both from the students and from the parents. Secondly, since students are not involved in the assessment process, this system does not contribute to the formation and development of educational independence, the ability to self evaluation, the need for action and improvement of their learning. Modern assessment should be multifunctional, understandable, and criteria-based [Arsova, 2021; Chernukha et al, 2021; Diachok et al, 2020; Goletiani et al, 2021; Nenkov et al, 2017; Linde \& Petrova, 2018].

Criteria-based assessment is often used in English lessons nowadays. The evaluation criteria for the subject are the subject educational goals, which, when translated into the language of the characteristics of the student, give a portrait of an ideally trained person. The criteria are deciphered by indicators, in which (for each specific job) a clear idea is given of how the result of the educational task should ideally look like, and evaluation by any indicator is the determination of the degree of approximation of the student to this goal [Alexander R., 2001] Culture and pedagogy. WileyBlackwell., pp 61-70]. With a competent design of indicators, the student can independently assess the quality of his work, which, in turn, stimulates him to achieve a higher result. Each work is evaluated according to a number of criteria and instructions for them. Criteria and instructions are developed during the social contract. We pay great attention to the fact that the evaluation is carried out for each task. Each task is evaluated according to the sum of points for each correctly performed element being checked. Criterion assessment performs a feedback function when students receive information about their success and failures. At the same time, even the most unsatisfactory results of intermediate work are perceived by students only as recommendations for improving their own 
results. The criteria based assessment describes the achievement levels corresponding to each score. It is important that the assessment scale starts from zero, and this is obvious, since it is not the student's personality that is evaluated, but his activity. Since the criterion approach to assessment should solve the problem of objective assessment of students and stimulate them to achieve a higher result, the range of problems in order of their significance may look as follows. Students will not immediately receive positive marks, as the process of adaptation to the new assessment system is underway. [Systema kriterialnogo otcenivaniya uchebnykh dostizhenii uchashikhsya. Metodicheskoye posobiye.-Astana: Natsionalnaya academia obrazovaniya im.I.Altynsarina, 2013.pp.80-81]

Now, 100-point system is actually used at colleges : 0-49 (dissatisfactory), 50-69 (satisfactory), 70-89 (good), 90-100 (excellent) when teacher sets the mark, he/she is oriented on the student's level relative to a certain standards of knowledge. Students should learn Criteria Listening the main content of texts allowing the inclusion of $1 \%$ of unfamiliar words -to understand the main content of texts of a monological and dialogical nature, built on program language material and allowing the inclusion of $1 \%$ of unfamiliar words, the meaning of which can be guessed from the context of texts of various genres the main idea information, to solve the problem -to perceive texts of various genres, highlighting their main idea and extracting information that is required to solve the problem; -use the listened information in other types of speech activity; -interpret and give your own assessment of the information.

Criteria for evaluating oral detailed answers (monologues, retellings, dialogues, project work, including in groups)

Oral answers are evaluated according to five criteria:

1. Content (compliance with the scope of the statement, compliance with the topic, reflection of all aspects specified in the task, stylistic design of speech, argumentation, compliance with the norms of politeness).

2. Interaction with the interlocutor (the ability to conduct a conversation logically and coherently, observe the order when exchanging remarks, give reasoned and detailed answers to the interlocutor's questions, the ability to start and maintain a conversation, as well as restore it in case of failure: repeat, clarification);

3. Vocabulary (vocabulary corresponds to the task and the requirements of this year of language training);

4. Grammar (using a variety of grammatical constructions in accordance with the task and the requirements of this year of language training);

5. Pronunciation (correct pronunciation of English sounds, correct accentuation in words, as well as observing the correct intonation in sentences) [Golnik Oksana, Novaya sistema $\mathrm{v}$ Kazakhstane, December 20.].

Table 1. Criteria for evaluating of writing

\begin{tabular}{|c|c|c|c|c|}
\hline Points & $\begin{array}{l}\text { Solving a communicative } \\
\text { problem }\end{array}$ & Text Organization & $\begin{array}{l}\text { Vocabulary and } \\
\text { grammar }\end{array}$ & $\begin{array}{l}\text { Spelling and } \\
\text { punctuation }\end{array}$ \\
\hline $100-90$ & $\begin{array}{l}\text { The task has been fully } \\
\text { completed: } \\
\text { 1. The content reflects all } \\
\text { the questions specified in } \\
\text { the assignment. } \\
\text { 2. The norms of politeness } \\
\text { are observed: the address is } \\
\text { correctly chosen, the final } \\
\text { phrase and signature, there } \\
\text { is gratitude. }\end{array}$ & $\begin{array}{l}\text { 1. The text is } \\
\text { logically } \\
\text { structured and } \\
\text { divided into } \\
\text { paragraphs. } \\
\text { 2. Correctly used } \\
\text { language means of } \\
\text { logical } \\
\text { communication. } \\
\text { 3. The design of } \\
\text { the text } \\
\text { corresponds to }\end{array}$ & $\begin{array}{l}\text { No more than } 2 \\
\text { grammatical } \\
\text { mistakes are } \\
\text { allowed }\end{array}$ & $\begin{array}{l}\text { The task should } \\
\text { be completed } \\
\text { without mistakes. }\end{array}$ \\
\hline
\end{tabular}




\begin{tabular}{|c|c|c|c|c|}
\hline & & $\begin{array}{l}\text { norms of written } \\
\text { etiquette. }\end{array}$ & & \\
\hline $89-70$ & $\begin{array}{l}\text { 1. One question is not fully } \\
\text { reflected. } \\
\text { 3.There are } 1-2 \text { violations }\end{array}$ & $\begin{array}{l}\text { the task coincides } \\
\text { the requirements } \\
\text { above }\end{array}$ & $\begin{array}{l}\text { No more than } 4 \\
\text { grammatical } \\
\text { mistakes are } \\
\text { allowed }\end{array}$ & $\begin{array}{l}\text { No more than } 2 \\
\text { grammatical } \\
\text { mistakes are } \\
\text { allowed }\end{array}$ \\
\hline $69-50$ & $\begin{array}{l}\text { 1. Two questions are not } \\
\text { fully reflected OR there is } \\
\text { no reflection of one of the } \\
\text { questions. } \\
\text { 2. More than } 2 \text { violations }\end{array}$ & $\begin{array}{l}\text { The text is mostly } \\
\text { logically } \\
\text { structured: there } \\
\text { are 1-2 violations. }\end{array}$ & $\begin{array}{l}\text { No more than } 5 \\
\text { grammatical } \\
\text { mistakes }\end{array}$ & $\begin{array}{l}\text { No more than } 3-4 \\
\text { mistakes are } \\
\text { allowed. }\end{array}$ \\
\hline $0-49$ & $\begin{array}{l}\text { The task does not } \\
\text { correspond the required } \\
\text { volume. }\end{array}$ & $\begin{array}{l}\text { The text is } \\
\text { illogically } \\
\text { constructed; } \\
\text { numerous } \\
\text { mistakes have } \\
\text { been made. } \\
\text { 2. OR the design } \\
\text { of the text does not } \\
\text { comply with the } \\
\text { norms of written } \\
\text { etiquette }\end{array}$ & $\begin{array}{l}\text { Numerous } \\
\text { language errors } \\
\text { have been made } \\
\text { that make it } \\
\text { difficult to } \\
\text { understand the } \\
\text { text. }\end{array}$ & $\begin{array}{l}\text { Numerous } \\
\text { mistakes have } \\
\text { been made } \\
\text { spelling and } \\
\text { punctuation } \\
\text { errors. }\end{array}$ \\
\hline
\end{tabular}

The maximum point is 100

Rating: "5" - 100-90 points (excellent)

"4" - 89-70 points (good)

"3"- 69- 50 points (satisfactory)

"2" - 49-0 points (unsatisfactory)

Self-assessment of students

Self-assessment as an integral part of the assessment of students' activities, a modern school is designed to create comfortable conditions for students. The humanization of education focuses on the subjective position of each student. There are no two identical answers, just as there are no two absolutely identical children. It is often difficult for a teacher to be objective. The problem of evaluating students' activities has always been and will always be relevant. One of the important aspects of assessment is students' self-assessment of their own scheduled and extracurricular activities. This work contains reflections on the self-assessment of students' activities from the perspective of technology for the development of critical thinking through reading and writing, as well as on the levels of success of students in educational and research activities in the process of learning a foreign language.

Self-assessment helps students to realize their achievements in learning English, as well as to identify gaps and weaknesses that require improvement. Acquaintance with the tables takes place at the first lesson on the topic, when working with the introductory page of each module, with the help of which children anticipate the thematic, lexical and grammatical content of the module, set new learning tasks, a clear picture of what they should learn while working on the module emerges. It is this "picture" that is drawn up in a table for subsequent self-assessment. Upon completion of work on each module in the control and correction lesson, after completing self-test tasks in the Progress Check section and the necessary exercises from the workbook, students fill out this self-assessment table, presenting their subjective opinion about the level of assimilation of the module material. I fill out this self-assessment table for each student after the control work, taking into account the assessment received for the control work, as well as the student's participation in various activities while working on the module and its promotion in general. Sample self-assessment tables are in the 
book for teachers to the Spotlight textbook by Yu.E. Vaulina, D. Dooley, O. E. Podolyako, V. Evans. These are the ones we took as a basis when compiling our tables, which we use at each lesson of correction and control after finishing work on the module in grades 5-7. These tables are also indispensable at the stage of reflection, when the student voices what he did well, what is not very good, what else needs to be worked on, thus setting himself new learning tasks. In the light of the strengthening of the subjective position of students in their own education, in addition to standard assessments, alternative forms of evaluating student activity, such as portfolio, rating, achievement scale, as well as various types of self-assessment, are becoming increasingly widespread.

Self-assessment sheet of students in every English lesson:

My participation in the lesson

My feelings and emotions during the lesson

My difficulties

Valuable thoughts for me from the lesson

Students emphasize the relationship between positive emotions in the lesson and successful assimilation of the material in the questionnaires. In everyday pedagogical practice, the object of control is the final result, therefore, the following forms can be used to form an adequate selfassessment of younger schoolchildren. Thanks to the differentiation of self-assessment and assessment, the students does not feel flawed, they understand that if something does not work out now, they will be able, with effort and practice, to complete the task later and demonstrate a positive result. [Golnik, 2020, p 54]

Parents of students should be involved in the process of forming adequate self-esteem and self-control skills so that there are uniform requirements at school and at home. At parent meetings and individual consultations, conversations are held about the ways of forming and the meaning of self-esteem and self-control. Parents who take part in the formation of their child's adequate selfesteem and self-control skills, subsequently really evaluate the opportunities and educational activities of their children. Experience shows that when teachers and parents work together, the results are higher and the goals set are achieved faster. A student with adequate self-esteem will be able to adjust and improve his educational and cognitive activities at college, and in the future will be able to self-actualize in adulthood.

Having such a table at hand, the student clearly understands what he needs to do and how to organize his work in stages in order to achieve the highest result. There is also a criteria based assessment in current lessons, for example, when forming and improving grammatical skills, when organizing work on vocabulary. While studying a new topic, I suggest that students evaluate the success of their work at each stage of the lesson.

\section{CONCLUSION}

Summing up, we can say that the assessment should be criteria-based, it does not depend on the subjective assessment of the teacher, and the main criteria are the expected results that correspond to the educational goals. It is not the student who is being evaluated, but the results he has achieved. Criteria-based assessment makes the assessment transparent. The presence of criteria for evaluating works gives the teacher operational information for the analysis and planning of his educational activities, the opportunity to improve the quality of teaching his subject and improve learning outcomes. Students consciously approach the performance of various kinds of tasks, take into account the proposed requirements, predict their own learning outcome and realize success and the reasons for failures, and, consequently, motivation and interest in learning English increases and, in general, the skill to learn is formed and develops. Criteria-based assessment should be used in the learning process, this is the future.

\section{REFERENCES:}

Alexander, R (2001) Culture and pedagogy: international comparison in primary education. Blackwell Publishers Oxford 
Arsova, D. (2021). Skills and competencies of the new generation of students to work with digital devices // "Innovations in technology and education": proceedings of XIV International scientific conference "Innovations in technology and education", 26 march 2021 г.: Kuzbass State Technical University, Belovo, Russia; 2021. - vol. 3., pp. 59-66 (in BG)

Chernukha, N., Petrova, M., Vasylieva-Khalatnykova, M., Krupnyk, Z., Krasilova, Y. (2021). The role of the Sociocultural Environment of Inclusion in the Modern Educational Institution. International Journal of Higher Education, Vol. 10, No. 3, June 2021, p.211-222, https://doi.org/10.5430/ijhe.v10n3p211

Diachok, N., Chernukha, N., Tokaruk, L., Udovenko, I., Petrova, M. (2020). Practical-oriented concept as a principle of professional education of the future professionals. International Journal of Higher Education, Vol. 9, No. 4, August 2020, pp.272-282, https://doi.org/10.5430/ijhe.v9n4p272

Golnik Oksana. (2020) Novaya sistema v Kazakhstane, December 20

Goletiani, K., Mushkudiani, Z., Gulua, E., Janelidze, N. (2021). Difficulties in managing diversity in Georgian educational organizations. Access to science, business, innovation in digital economy, ACCESS Press, 2(2): 123-137. https://doi.org/10.46656/access.2021.2.2(1)

Kriventsova E.E, Gunina N.A. [2016] Systema kriteriayalnogo otsenivaniya kak instrument izmereniya kachestva obrazovaniya : tekushee i itogovoye otsenivaniye [System of criterial assessment as instrument of evaluation of quality of education: current and final assessment] FGKOU MKK«Pansion vospitannic Ministerstva oborony RF» Moscow [in Russian]

Linde, I., Petrova, M. (2018) The challenges of formalization and modeling of Higher Education Institutions in the 21st century. CBU International conference proceedings 2018: Innovations in Science and Education, 21.-23.03.2018, pp.303-308, https://doi.org/10.12955/cbup.v6.1173

Nenkov, N., Dyachenko, Yu., Petrova, M., Bondarenko, G., Pustovit, V. (2017). Intelligent and Cognitive Technologies in Education of International Economic Relations Students and Human Resource Development in Enterprises: Methodology in Language. European Journal of Sustainable Development, Publisher: European Center of Sustainable Development, ISSN 22395938 (print), ISSN 2239-6101(online), http://www.ecsdev.org/, Rome, Italy, Vol 6, No.4, 2017, pp.353-360, https://doi.org/10.14207/ejsd.2017.v6n4p353

Petrova, M., Aleksandrov, M. (2018). Automating the virtual hosts maintenance in a multi-site environment. International Congress on Business and Marketing (ICBM'18), Marmara Eğitim Köyü Maltepe / İstanbul, TÜRKIYYE, Proceedings of the International Congress on Business and Marketing, 2018 Maltepe University, Istanbul, ISBN 978-605-2124-09-03, p.392-404

Systema kriterialnogo otcenivaniya uchebnykh dostizhenii uchashikhsya. Metodicheskoye posobiye [System of criterial assessment of academic achievements. Mthodical textbook]-Astana: Natsionalnaya academia obrazovaniya im.I.Altynsarina, 2013.pp.80-81 [in Russian] 